\title{
The conservation value of karst dolines for vascular plants in woodland habitats of Hungary: refugia and climate change
}

\author{
Zoltán Bátori ${ }^{*}$, János Csiky², Tünde Farkas ${ }^{3}$, Anna E. Vojtkó ${ }^{4}$, László Erdős ${ }^{1}$, \\ Dániel Kovács ${ }^{2}$, Tamás Wirth ${ }^{2}$, László Körmöczi ${ }^{1}$, and András Vojtkó ${ }^{5}$ \\ ${ }^{1}$ University of Szeged, Department of Ecology, H-6726 Szeged, Közép fasor 52, Hungary \\ ${ }^{2}$ University of Pécs, Department of Plant Taxonomy and Geobotany, H-7624 Pécs, Ifjúság útja 6, Hungary \\ ${ }^{3}$ Directorate of the Aggtelek National Park, H-3758 Jósvafö, Tengerszem oldal 1, Hungary \\ ${ }^{4}$ University of Debrecen, Department of Botany, H-4032 Debrecen, Egyetem tér 1, Hungary \\ ${ }^{5}$ Eszterházy Károly College, Department of Botany, H-3300 Eger, Leányka utca 6, Hungary
}

\begin{abstract}
Limestone (karst) surfaces in Hungary are rich in dolines, in which many endangered vascular plant species occur. To date, the majority of studies dealing with doline vegetation have focused on the local rather than the landscape level, without using comparative data from other areas. However, in this study we aimed to compare the vegetation pattern and species composition of dolines under different climate regimes of Hungary with regard to regional species pools. The fieldwork was carried out between 2005 and 2012. Twenty dolines were selected in the Mecsek Mountains (southern Hungary) and nine dolines in the Aggtelek Karst area (northern Hungary). More than 900 vascular plants and more than 2000 plots were included in the study. The moving split window (MSW) technique, nestedness analysis and principal coordinates analysis (PCoA) were used to reveal the vegetation patterns in dolines. Although we found remarkable differences between the species composition of the two regions, dolines of both regions play a similar role in the preservation of different groups of species. Many plants, in particular mountain species, are restricted to the bottom of dolines where appropriate environmental conditions exist. In addition, depending on the doline geometry, many species of drier and warmer forests have colonized the upper slopes and rims. Thus, we can conclude that karst dolines of Hungary can be considered as reservoirs for many vascular plant species, therefore they are particularly important from a conservation point of view. Moreover, these dolines will likely become increasingly indispensable refugia for biodiversity under future global warming.
\end{abstract}

Keywords: $\quad$ Aggtelek Karst area; global warming; Mecsek Mountains; relict species; transects

Received 28 January 2013; Revised 8 June 2013; Accepted 15 October 2013

Citation: Bátori Z., Csiky J., Farkas T., Vojtkó A.E., Erdős L., Kovács D., Wirth T., Körmöczi L. and Vojtkó A. 2014. The conservation value of karst dolines for vascular plants in woodland habitats of Hungary: refugia and climate change. International Journal of Speleology, 43 (1), 15-26. Tampa, FL (USA) ISSN 0392-6672 http://dx.doi.org/10.5038/1827-806X.43.1.2

\section{INTRODUCTION}

Habitat destruction together with climate induced species extinction and surface contamination are the main threats to the biological and geological diversity of karst surfaces (cf. Schilthuizen et al., 2005; Breg, 2007). Although karst ecosystems are usually diverse and are very important in many aspects of ecological research (e.g. Cardoso, 2012; Novak et al., 2012), there are still many open questions about how karst surfaces will change under future global warming.

Based on previous studies, we expect remarkable differences between the role of subsurface cavities (e.g. caves) and surface forms (e.g. dolines) in the preservation of different groups of species. Caves and wells serve as habitats for many subterranean species
(Culver et al., 1973; Culver \& Sket, 2000; Dixon, 2011), while dolines may preserve relicts (Horvat, 1953; Stuckey, 1983; Bátori et al., 2009), mountain species (Beck v. Mannagetta, 1906; Vojtkó, 1997; Bátori et al., 2006), endemic species (Egli, 1991; Barnard et al., 1998) and endemic plant communities (Redžić et al., 2011). The biological literature contains many excellent examples where dolines have been mentioned as key habitats for scientifically important plant species. From a biogeographical perspective, for instance, Biebersteinia orphanidis (Peloponnisos, Greece), Cerastium dinaricum (Dinarian Mountains, Slovenia), Dracocephalum ruyschiana (Pešter plateau, Serbia; Bükk Mountains, Hungary), Horstrissea dolinicola (Crete, Greece), Pulsatilla vernalis (Julian Alps, Slovenia) and Stachys alpina (Mecsek Mountais, 
Hungary) are especially good examples (Bartha, 1933; Egli et al., 1990; Wraber, 1995; Yannitsaros et al., 1996; Dakskobler et al., 2008; Bátori et al., 2009; Lazarević et al., 2009). Since dolines harbour many vascular plant species that are missing or are very rare in the surrounding habitats, they can be considered habitat islands (Bátori et al., 2012). The different amount of solar radiation on the different parts of the slopes has resulted in local environmental gradients (e.g. air temperature, air humidity and soil moisture), which in turn strongly influence the composition of flora and vegetation on the slopes with different orientation at the same altitude (Beck v. Mannagetta, 1906; Horvat, 1953; Gargano et al., 2010; Bátori et al., 2011). It also means that a high species diversity within short distances can be observed (Özkan et al., 2010).

While many studies on the ecological role of dolines have focused mainly on local vegetation changes (e.g. floristic composition and vegetation inversion) (e.g. Lausi, 1964), relatively few studies have been designed to evaluate the correspondences between the local and regional flora (e.g. Egli, 1993). The relationship between the local species pool (i.e., the flora of a doline) and the regional species pool (i.e., the flora of a karst surface) informs us about how dolines play a role in the preservation of different groups of species. Our aims were: to investigate how regional climate influences the flora of dolines and their surroundings; to investigate what correspondence can be detected between the species composition of dolines and the landscape; to examine how the vascular plant species composition changes in different-sized dolines.

\section{MATERIAL AND METHODS}

\section{Study regions and study sites}

The fieldwork was carried out on a karst surface of 30 $\mathrm{km}^{2}$ in the Mecsek Mountains (southern Hungary), and on a karst surface of $5 \mathrm{~km}^{2}$ in the Aggtelek Karst area (northern Hungary) between 2005 and 2012 (Fig. 1).

On the karst surface of the Mecsek Mountains, there are more than 2000 solution dolines located between 250 and $500 \mathrm{~m}$ above sea level. Most of them are very small (diameter $<20 \mathrm{~m}$ ). The average diameter is between 20 and $40 \mathrm{~m}$. The diameter of the largest doline is over $200 \mathrm{~m}$ and its depth exceeds $30 \mathrm{~m}$ (Lovász, 1971). Due to these topographic differences, the ecological conditions (e.g. soil moisture, air humidity) of the dolines are highly variable (Bátori et al., 2011). The average annual rainfall of the study region exceeds $700 \mathrm{~mm}$. Due to the sub-Mediterranean climate, the monthly maximum values during summer $(77 \mathrm{~mm}$ in both May and June) and autumn (72 $\mathrm{mm}$ in October). The annual mean temperature is about $9.5^{\circ} \mathrm{C}$, with the highest mean temperature of $19.3{ }^{\circ} \mathrm{C}$ in July. Winters are moderately cold with a mean temperature of $-1.1{ }^{\circ} \mathrm{C}$ between December and February (Ádám et al., 1981; Marosi \& Somogyi, 1990). The investigated dolines are situated in the oak-hornbeam belt of the mountain range, in the mosaics of Illyrian type oak-hornbeam (Asperulo taurinae-Carpinetum) and beech forests (Helleboro odori-Fagetum) with the age of 70-110 years. The bottom of larger dolines is often covered by fragments of ravine forests (Scutellario altissimae-Aceretum) (Bátori et al., 2012). Some dry grassland and hay meadow patches, moist habitats and trampled places also occur both on the plateaus and in the valleys of the study region.

Vecsembükk is a part of the Aggtelek Karst area characterised by more than 150 solution dolines located between 400 and $600 \mathrm{~m}$ above sea level. The average doline size is much larger (80 to $100 \mathrm{~m}$ in diameter) than in the Mecsek Mountains. The diameter of the largest doline is over $350 \mathrm{~m}$ and its depth exceeds $50 \mathrm{~m}$. Average annual rainfall is more than $650 \mathrm{~mm}$ with the monthly maximum during summer ( $85 \mathrm{~mm}$ in June). Annual mean temperature is about $9.1^{\circ} \mathrm{C}$, with the highest mean temperature of $20.3{ }^{\circ} \mathrm{C}$ in July. Due to the continental climate, winters are cold with a mean temperature of $-2.5{ }^{\circ} \mathrm{C}$ from December to February (Ujvárosy, 1998). The investigated dolines are often surrounded by 60-110 years old Central European type oak-hornbeam (Carici pilosae-Carpinetum) and beech forests (Melittio-Fagetum) consisting of some high mountain plant species like Dryopteris expansa, Polygonatum verticillatum or Rosa pendulina. Dolines are often covered by scree forests (Mercuriali-Tilietum and Tilio-Fraxinetum) or fragments of ravine forests (Scolopendrio-Fraxinetum) (Vojtkó, 2003; 2004).

\section{Sampling}

Investigations were performed at two different levels: (1) at the level of each doline and (2) at the level of the karst surfaces. A total of 29 dolines were studied: 20 in the Mecsek Mountains and 9 in the Aggtelek Karst area. Dolines were selected randomly from two size classes of dolines (diameter $\leq 100 \mathrm{~m}$ and diameter $>100 \mathrm{~m}$ ). Dolines ranked by diameter are identified with capital letters from $A_{m}$ to $T_{m}$ for the Mecsek Mountains, and $\mathrm{A}_{\mathrm{a}}$ to $\mathrm{I}_{\mathrm{a}}$ for the Aggtelek Karst area (Table 1).

Vascular plant species lists were compiled between 2005 and 2012 for 20 dolines $\left(A_{m}\right.$ to $T_{m}$ ) of the Mecsek Mountains and 8 dolines $\left(\mathrm{A}_{\mathrm{a}}\right.$ to $\mathrm{C}_{\mathrm{a}} ; \mathrm{E}_{\mathrm{a}}$ to $\left.\mathrm{I}_{\mathrm{a}}\right)$ of the Aggtelek Karst area. Species data were collected from early March to late October for the total area of dolines. The total area included the area of the slopes (where the slope angle was over $10^{\circ}$ ) and the area of the rims, an approximately 1 to $5 \mathrm{~m}$ wide strip around

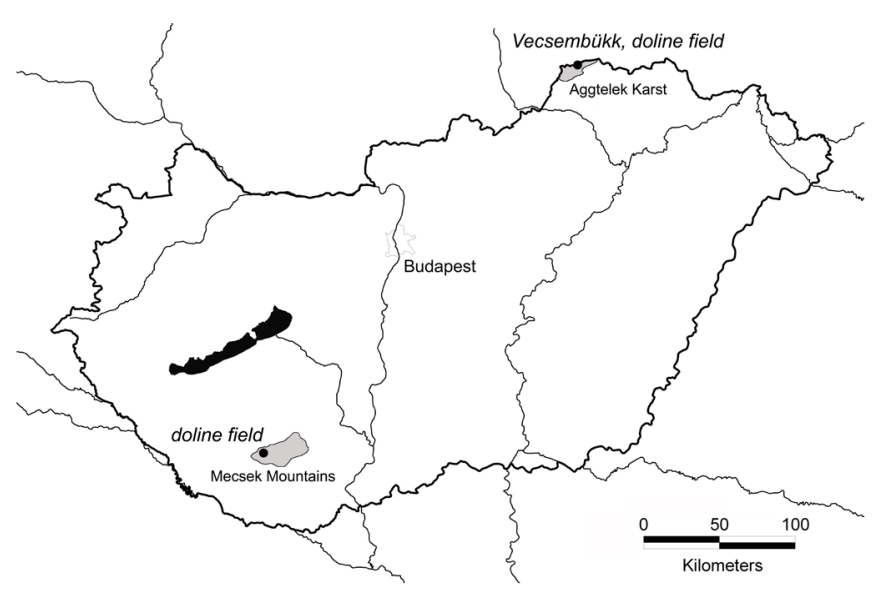

Fig. 1. Location of the study regions in Hungary. 
Table 1. Diameter and depth values and depth/diameter ratios of the studied dolines of the Mecsek Mountains $\left(A_{m}-T_{m}\right)$ and the Aggtelek Karst area $\left(\mathrm{A}_{\mathrm{a}}-\mathrm{I}_{\mathrm{a}}\right)$.

\begin{tabular}{|c|c|c|c|c|c|c|c|c|c|c|c|c|c|c|c|}
\hline \multicolumn{3}{|c|}{ Dolines } & $A_{m}$ & $\mathrm{~B}_{\mathrm{m}}$ & $\mathrm{C}_{\mathrm{m}}$ & $D_{m}$ & $\mathrm{E}_{\mathrm{m}}$ & $\mathrm{F}_{\mathrm{m}}$ & $\mathrm{G}_{\mathrm{m}}$ & $\mathrm{H}_{\mathrm{m}}$ & $I_{m}$ & $\mathrm{~J}_{\mathrm{m}}$ & $\mathrm{K}_{\mathrm{m}}$ & $\mathrm{L}_{\mathrm{m}}$ & $M_{m}$ \\
\hline \multicolumn{3}{|c|}{ diameter } & 5 & 8 & 10 & 15 & 20 & 20 & 25 & 40 & 60 & 60 & 70 & 70 & 75 \\
\hline \multicolumn{3}{|c|}{ depth (m) } & 0.5 & 2 & 2 & 3 & 4.5 & 3 & 5.5 & 10 & 11 & 11 & 14 & 14 & 11 \\
\hline \multicolumn{3}{|c|}{ depth/diameter } & 0.10 & 0.25 & 0.20 & 0.20 & 0.23 & 0.15 & 0.22 & 0.25 & 0.18 & 0.18 & 0.20 & 0.20 & 0.15 \\
\hline $\mathrm{N}_{\mathrm{m}}$ & $\mathrm{O}_{\mathrm{m}}$ & $P_{m}$ & $Q_{m}$ & $\mathrm{R}_{\mathrm{m}}$ & $\mathrm{S}_{\mathrm{m}}$ & $\mathrm{T}_{\mathrm{m}}$ & $\mathrm{A}_{\mathrm{a}}$ & $\mathrm{B}_{\mathrm{a}}$ & $\mathrm{C}_{\mathrm{a}}$ & $\mathrm{D}_{\mathrm{a}}$ & $\mathrm{E}_{\mathrm{a}}$ & $\mathrm{F}_{\mathrm{a}}$ & $\mathrm{G}_{\mathrm{a}}$ & $\mathrm{H}_{\mathrm{a}}$ & $\mathrm{I}_{\mathrm{a}}$ \\
\hline 100 & 100 & 135 & 135 & 135 & 150 & 190 & 40 & 60 & 70 & 70 & 90 & 120 & 120 & 120 & 150 \\
\hline 15 & 16 & 24 & 20 & 20 & 18 & 28 & 15 & 15 & 15 & 15 & 20 & 20 & 20 & 30 & 40 \\
\hline 0.15 & 0.16 & 0.18 & 0.15 & 0.15 & 0.12 & 0.15 & 0.38 & 0.25 & 0.21 & 0.21 & 0.22 & 0.17 & 0.17 & 0.25 & 0.27 \\
\hline
\end{tabular}

the smaller dolines, and an approximately 10 to $20 \mathrm{~m}$ wide strip around the larger dolines where the slope angle was less than $10^{\circ}$. Each doline was visited at least 10 times during the investigation period. Finally, a species list for both karst surfaces (Aggtelek Karst area, Vecsembükk: $5 \mathrm{~km}^{2}$, Mecsek Mountains: 30 $\mathrm{km}^{2}$ ) was obtained from the database of the Central European Flora Mapping Programme (CEU) and from detailed field observations. During field studies, the most typical habitat type of each species was also recorded (i.e., the habitat preferred by a species in the study regions).

Transects for sampling the herb layer were established across the 20 dolines $\left(A_{m}\right.$ to $\left.T_{m}\right)$ of the Mecsek Mountains in a north-south direction, passing through the deepest point of the depressions. Transects begun and ended in the surrounding forests, according to our former study (Bátori et al., 2012). In the case of the Aggtelek Karst area, 4 dolines $\left(\mathrm{B}_{a}\right.$; $D_{a} ; E_{a} ; G_{a}$ ) were sampled with the same method. Each transect consisted of a series of $1 \mathrm{~m} \times 1 \mathrm{~m}$ contiguous plots. Percentage cover of each vascular herb and tree sapling was estimated visually in the plots. A total of 2220 plots were recorded.

The diameter and depth values of dolines were also measured in both regions (without considering the doline rim) (Table 1), from which depth/diameter ratios were determined.

\section{Species grouping}

All vascular plant species found in the karst surfaces were classified according to their coenological preferences (Soó, 1980). Finally, 13 large groups of species were established: $\left(\mathrm{Sg}_{1}\right)$ species of dry oak forests (e.g. Acer tataricum, Betonica officinalis, Quercus cerris, Sorbus torminalis, Viola hirta), $\left(\mathrm{Sg}_{2}\right)$ species of mesic oak forests (e.g. Acer campestre, Convallaria majalis, Galium schultesii, Ligustrum vulgare, Melica uniflora), $\left(\mathrm{Sg}_{3}\right)$ species of Central European beech forests (e.g. Acer pseudoplatanus, Allium ursinum, Carex pilosa, Fagus sylvatica, Milium effusum), $\left(\mathrm{Sg}_{4}\right)$ species of Illyrian beech forests (e.g. Asperula taurina subsp. leucanthera, Helleborus odorus, Ruscus aculeatus, Ruscus hypoglossum, Tamus communis), $\left(\mathrm{Sg}_{5}\right)$ species of deep ravines and gorges (e.g. Aruncus dioicus, Asplenium scolopendrium, Lunaria rediviva, Polystichum aculeatum, Silene dioica), $\left(\mathrm{Sg}_{6}\right)$ species of wet forests (e.g. Alnus glutinosa, Carex remota, Chrysosplenium alternifolium, Festuca gigantea, Salix alba), $\left(\mathrm{Sg}_{7}\right)$ species of dry grasslands (e.g. Achillea pannonica, Festuca rupicola, Fragaria viridis, Salvia pratensis, Vicia angustifolia), $\left(\mathrm{Sg}_{8}\right)$ species of mesic hay meadows (e.g. Alopecurus pratensis, Arrhenatherum elatius, Holcus lanatus, Pastinaca sativa, Poa pratensis), ( $\left.\mathrm{Sg}_{9}\right)$ species of marshes (e.g. Carex acutiformis, Galium palustre, Lycopus europaeus, Phragmites australis, Typha latifolia), $\left(\mathrm{Sg}_{10}\right)$ weeds (e.g. Ballota nigra, Capsella bursapastoris, Chenopodium album, Hordeum murinum, Poa bulbosa), $\left(\mathrm{Sg}_{11}\right)$ adventive species (e.g. Acer negundo, Amorpha fruticosa, Ambrosia artemisiifolia, Quercus rubra, Robinia pseudoacacia), $\left(\mathrm{Sg}_{12}\right)$ indifferent species (e.g. Achillea collina, Carex hirta, Coronilla varia, Plantago media, Urtica dioica), $\left(\mathrm{Sg}_{13}\right)$ species of other habitats (e.g. species of acidic forests) (e.g. Betula pendula, Castanea sativa, Luzula luzuloides, Lychnis viscaria, Veronica officinalis) (Table 2). The group of $\mathrm{Sg}_{5}$ together with other plant species of high altitudes that are classed in various other groups are referred to as „mountain” species throughout this paper.

\section{Statistical analyses}

The moving split window (MSW) technique (Webster, 1978), based on percent cover data, was used as a quantitative identification of boundary location along the transects (Fig. 2). This method calculates dissimilarity coefficients between split windows by moving a sampling unit from one end of a transect to the other end. The complement of the Renkonen index (DREN) was applied as the comparative function, since it is sensitive to species composition changes (Zalatnai \& Körmöczi, 2004; Körmöczi, 2005). Significance of the boundaries was tested using the $z$-score transformation:

$$
z=\left(d_{i, k}-d_{\text {exp }, k}\right) / S D_{\text {exp }, k}
$$

where $z$ is the $z$-score, $d_{i, k}$ is the DREN at position $i$ if the half-window size is $k, d_{\text {exp, },}$ is the overall mean of DREN from randomized data for the half-window size $k$ (expected mean), and $S D_{\text {exp, },}$ is the standard deviation of the DREN values from the randomized data for the halfwindow size $k$. Random reference was made with plot randomization and 1000 randomizations were done. $\mathrm{Z}$-scores were plotted against the window midpoint position. In this profile, vegetation boundaries appear 


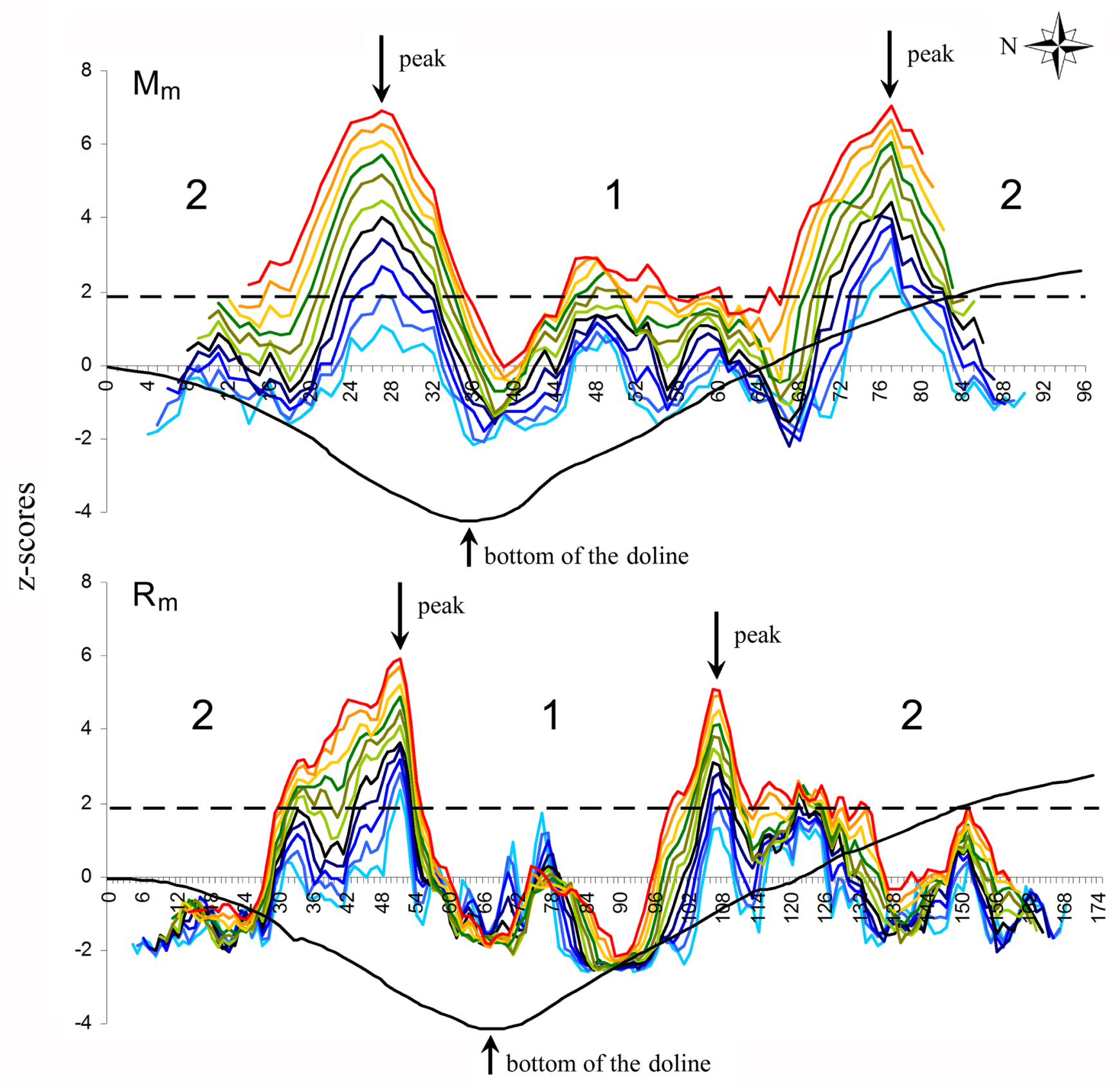

position along the transects $(\mathrm{m})$

half-window size:

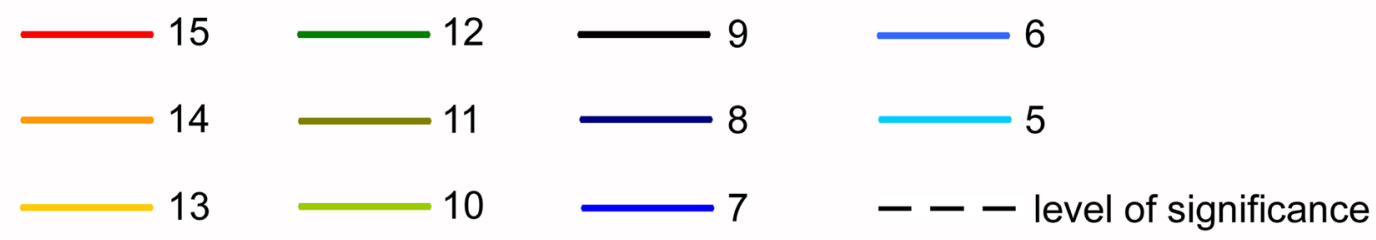

Fig. 2. Representative z-score profiles of transects in two dolines $\left(M_{m}, R_{m}\right)$ of the Mecsek Mountains with the different doline parts (No. 1 and No. 2) and morphological profiles. 
as peaks. Z-scores for each window midpoint position were calculated from 1 to 5 half-window sizes for smaller dolines and from 5 to 15 half-window sizes for larger dolines. Z-scores above 1.85 were considered indicative of significant $(\mathrm{p}<0.05)$ boundaries (Körmöczi, 2011). Positions where most of the $z$-score profiles were above 1.85 were considered real vegetation boundaries (Fig. 2). MSW computations were done using the statistical language R 2.10.1 (R Development Core Team, 2009).

Each transect was divided into two parts according to the results of MSW (Fig. 2). The first part always consisted of the bottom of the dolines and the lower parts of the slopes (No. 1 in the profile), while the second part consisted of the upper parts of the slopes and the rims (No. 2 in the profile). Finally, the proportions of the species groups (weighted by species occurrences in the plots) of both parts were calculated and used to assess the floristic differences between them (Fig. 3, 4). In many cases, the species composition of the upper doline slopes and the rims is the same as (or very similar to) that of the surrounding forests (cf. Bátori et al., 2012; Vojtkó, 2003), therefore this division is appropriate to compare the vegetation of the doline bottoms with that of their surroundings.

Principal coordinates analysis (PCoA), based on presence-absence data and Euclidean distance, was carried out to reveal the vegetation patterns in the dolines (Fig. 5, 6). Vegetation types in the scatter plots were identified according to the results of MSW and field observations.

Species-area relations (Arrhenius, 1921) were assessed for all plant species, as well as for the groups of $\mathrm{Sg}_{1}$ and $\mathrm{Sg}_{2}$ (i.e., oak forest) species, $\mathrm{Sg}_{3}$ and $\mathrm{Sg}_{4}$ (i.e., beech forest) species and $\mathrm{Sg}_{5}, \mathrm{Sg}_{6}$ and $\mathrm{Sg}_{9}$ (i.e., cool-adapted) species (Fig. 7, 8). The Nestedness Temperature Calculator (NTC) of Atmar \& Patterson (1993, 1995) was used to explore various features of nestedness of the flora of dolines (http://aics-research. com/nestedness/tempcalc.html). The degree of nestedness of the presence/absence matrix was quantified by using the matrix's temperature $(T)$ and by assessing the statistical significance of nestedness. $T$ ranges

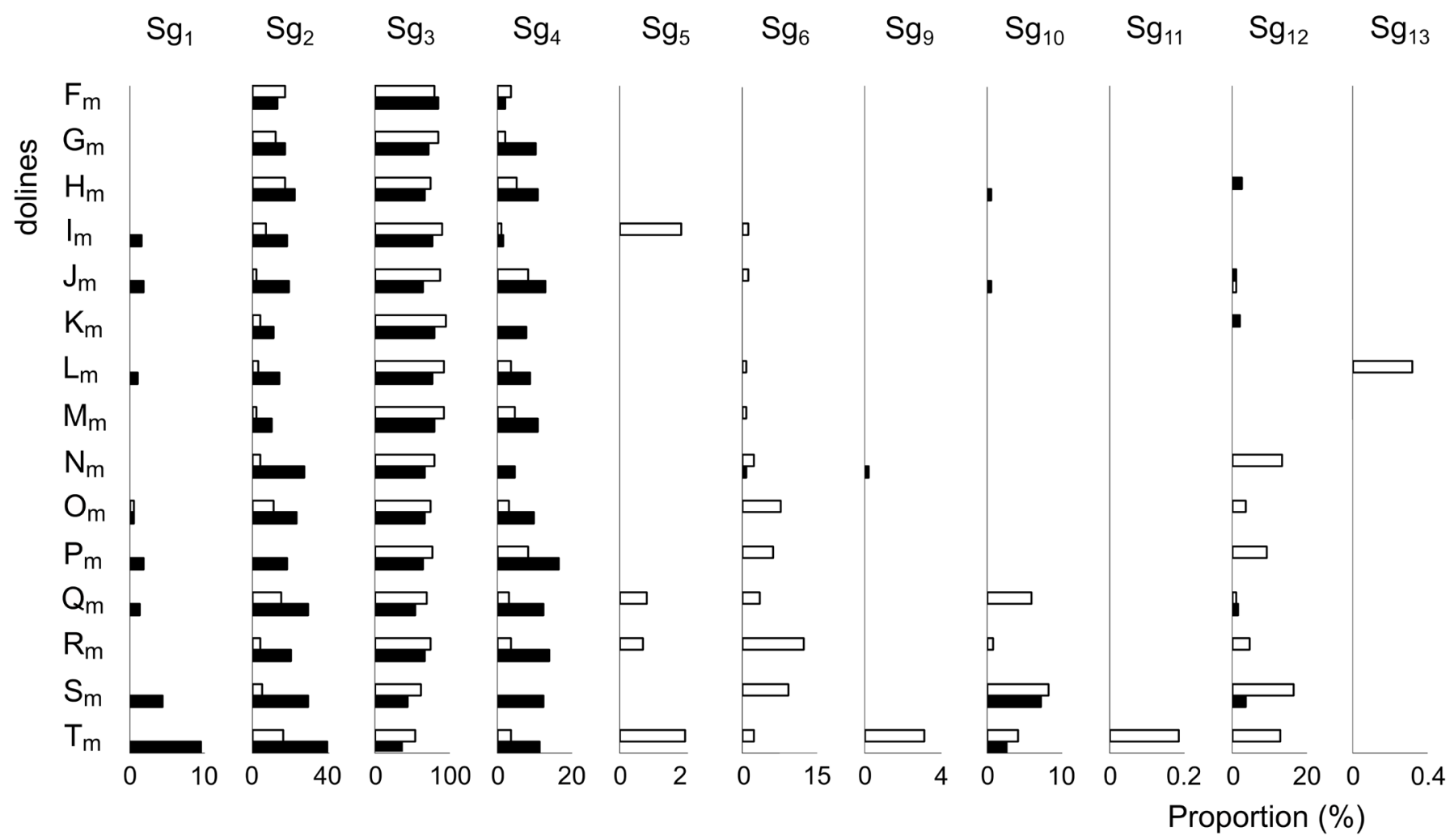

Fig. 3. Proportions of the different species groups in the dolines of the Mecsek Mountains. White and black bars refer to the proportions of the $1^{\text {st }}$ and $2^{\text {nd }}$ vegetation units, respectively.

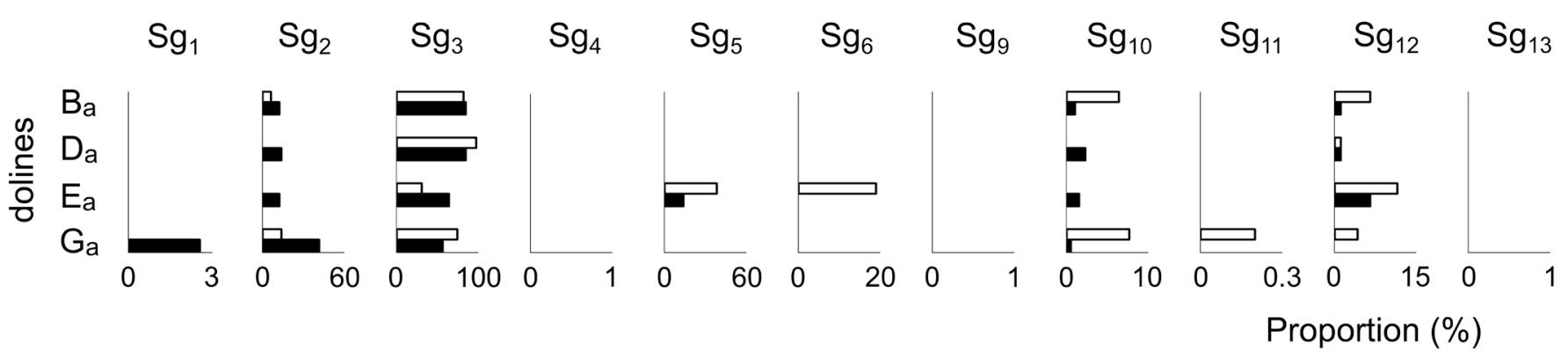

Fig. 4. Proportions of the different species groups in the dolines of the Aggtelek Karst area. White and black bars refer to the proportions of the $1^{\text {st }}$ and $2^{\text {nd }}$ vegetation units, respectively. 


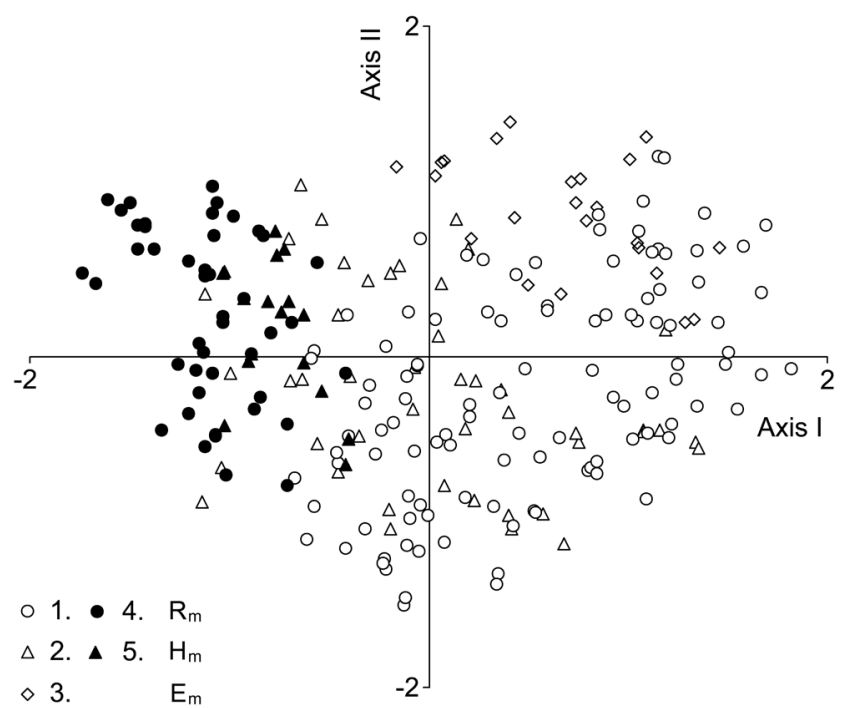

Fig. 5. Representative PCoA scatter diagram for the plots of three dolines $\left(E_{m}, H_{m}, R_{m}\right)$ of the Mecsek Mountains. Notation: 1. plots of the beech forest (Helleboro odori-Fagetum) and oak-hornbeam forest (Asperulo taurinae-Carpinetum) of doline $\mathrm{R} ; 2$. plots of the beech forest and oak-hornbeam forest of doline $\mathrm{H}_{m}$; 3 . plots of the beech forest and oak-hornbeam forest of doline $E_{m}^{m} ; 4$. plots of the ravine forest (Scutellario altissimae-Aceretum) of doline $R_{m} ; 5$ : plots of the ravine forest of doline $\mathrm{H}_{\mathrm{m}}$. Variance explained by the first and second axes was $19.9 \%$ and $10.8 \%$, respectively.

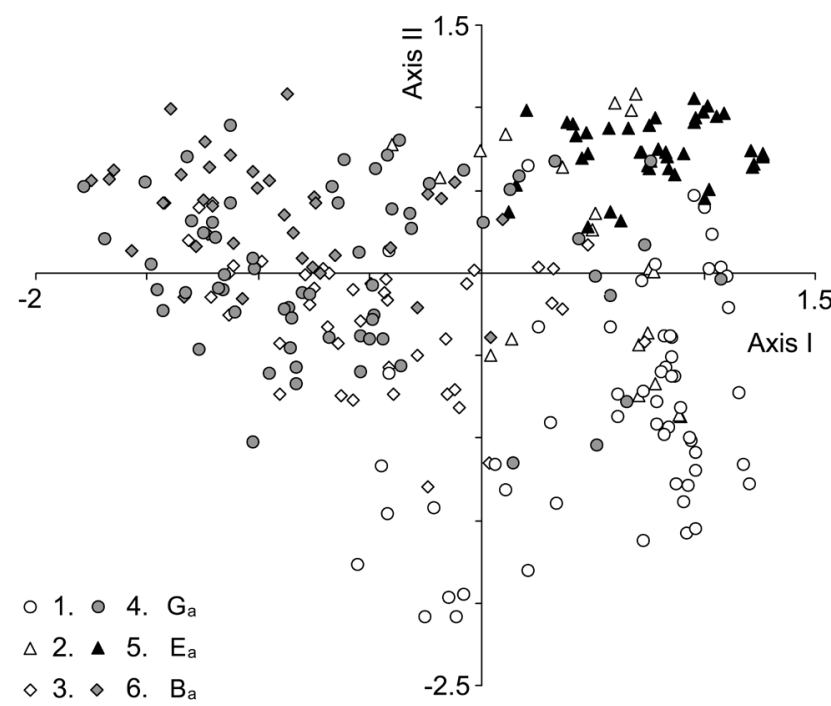

Fig. 6. Representative PCoA scatter diagram for the plots of three dolines $\left(B_{a}, E_{a}, G_{a}\right)$ of the Aggtelek Karst area. Notation: 1. plots of the beech forest (Melittio-Fagetum) and oak-hornbeam forest (Carici pilosae-

Carpinetum) of doline $\mathrm{G}_{\mathrm{a}} ; 2$. plots of the beech forest and oak-hornbeam forest of doline $E_{a}$; 3 . plots of the beech forest and oak-hornbeam forest of doline $B_{a} ; 4$. plots of the scree forest (Mercuriali-Tilietum) of doline $G_{a}$; 5: plots of the ravine forest (Scolopendrio-Fraxinetum) of doline $\mathrm{E}_{2} ; 6$ : plots of the scree forest of doline $B_{a}$. Variance explained by the first and second axes was $15.7 \%$ and $10.5 \%$, respectively.

from 1 (cold) to 100 (hot), where 1 indicates the perfect nestedness, and 100 indicates the complete disorder. Since our matrix was not square (i.e., equal number of rows and columns) and fill was less than 50\%, the matrix has been randomized using Monte Carlo simulations by 500 times to get the average $T$ of the random matrices $\left(T_{\text {rand }}\right)$. Plant species that contributed to the matrix disorder the most were also determined.

Plant species names were used according to Király (2009).

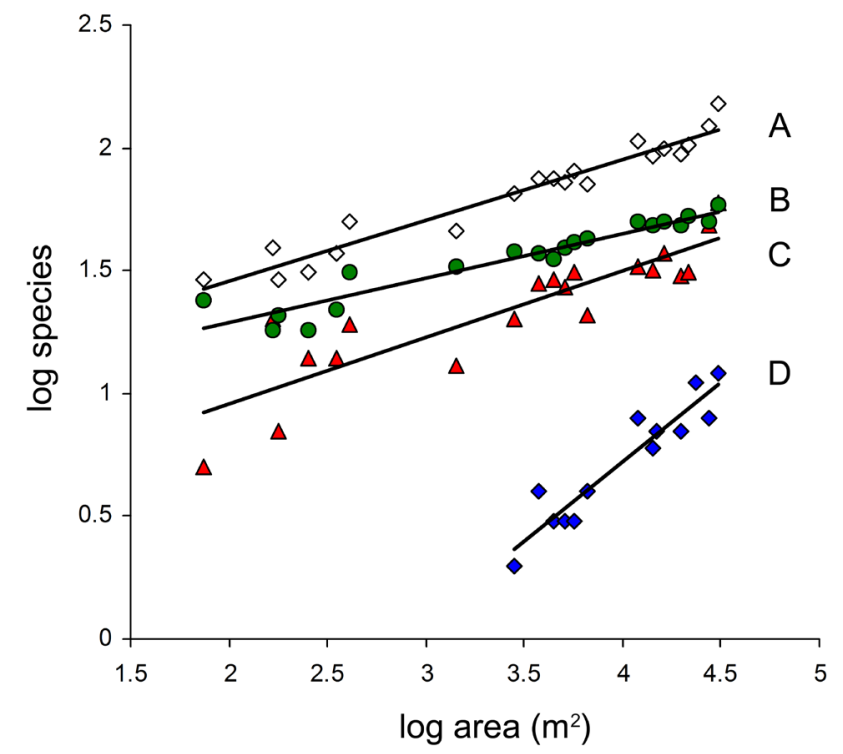

Fig. 7. Relationship between doline area ( $\log _{10}$ transformed) and species number $\left(\log _{10}\right.$ transformed) for the vascular vegetation of the Mecsek Mountains. Species-area lines were determined for all plant species (A: $y=0.2491 x+0.9588, R=0.9694)$ and for the groups of beech forest species (B: $y=0.1819 x+0.9247, R=0.9506)$, oak forest species (C: $y=0.273 x-0.4083, R=0.8789$ ) and cool-adapted species (D: $y=0.6507 x-1.8830, R=0.9405$ ).

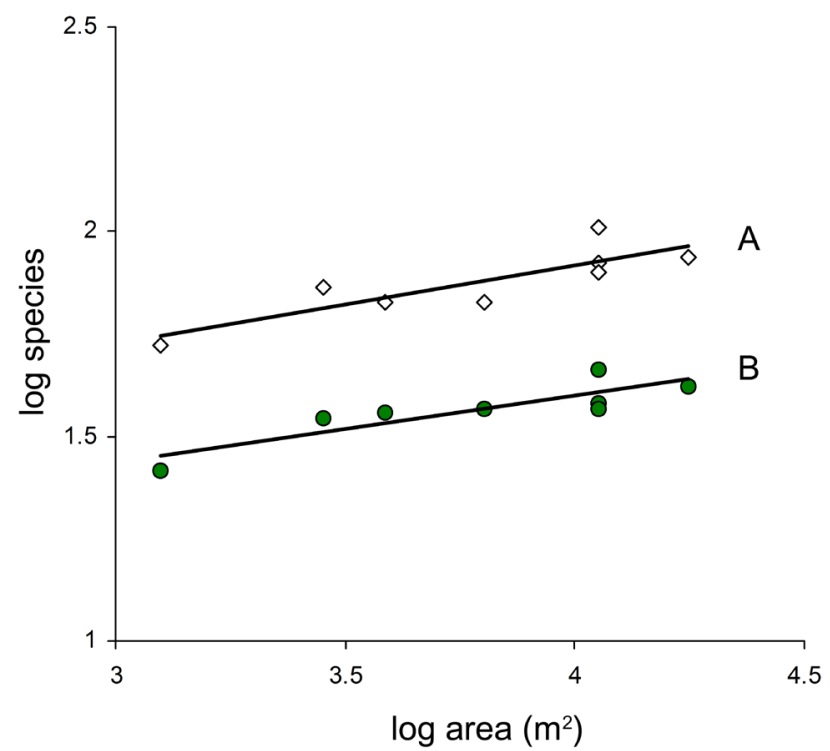

Fig. 8. Relationship between doline area ( $\log _{10}$ transformed) and species number $\left(\log _{10}\right.$ transformed) for the vascular vegetation of the Aggtelek Karst area. Species-area lines were determined for all plant species (A: $y=0.1926 x+1.1463, R=0.8590)$ and for the groups of beech forest species (B: $y=0.1614 x+0.9524, R=0.8698)$.

\section{RESULTS}

The species composition of the karst surface in the Mecsek Mountains $\left(30 \mathrm{~km}^{2}\right)$ was rather diverse (Table 2) with a total of 750 vascular plant species from 13 species groups. Many of the forests were dominated by $\mathrm{Sg}_{2}, \mathrm{Sg}_{3}$ and $\mathrm{Sg}_{4}$ species, while $\mathrm{Sg}_{1}$ species occurred mainly on warm, south-facing slopes and $\mathrm{Sg}_{6}$ species in cool and moist habitats (e.g. valleys and dolines). $\mathrm{Sg}_{7}$ species were dominant on rocky outcrops and in dry grasslands, $\mathrm{Sg}_{8}$ species in meadows and $\mathrm{Sg}_{9}$ species in small lakes and marshes. $\mathrm{Sg}_{10}$ and $\mathrm{Sg}_{11}$ species inhabited the roadsides, the plantations and other disturbed places of the karst surface. $\mathrm{Sg}_{5}$ 
Table 2. Proportions of the species groups and total number of plants in the dolines of the Mecsek Mountains ( $\left.A_{m}-T_{m}\right)$ and in the Aggtelek Karst area $\left(\mathrm{A}_{\mathrm{a}}-\mathrm{I}_{\mathrm{a}}\right)$. Framed rectangles indicate the highest proportions. Abbreviations: $\mathrm{Sr}_{\mathrm{m}}$ : study region of the Mecsek $\left.\mathrm{Mountains}(30 \mathrm{~km})^{2}\right)$, Sr $\mathrm{r}_{\mathrm{a}}$ : study region of the Aggtelek Karst area $\left(5 \mathrm{~km}^{2}\right)$; tns: total number of species.

\begin{tabular}{|c|c|c|c|c|c|c|c|c|c|c|c|c|c|c|}
\hline & $\mathrm{Sg}_{1}$ & $\mathrm{Sg}_{2}$ & $\mathrm{Sg}_{3}$ & $\mathrm{Sg}_{4}$ & $\mathrm{Sg}_{5}$ & $\mathrm{Sg}_{6}$ & $\mathrm{Sg}_{7}$ & $\mathrm{Sg}_{8}$ & $\mathrm{Sg}_{9}$ & $\mathrm{Sg}_{10}$ & $\mathrm{Sg}_{11}$ & $\mathrm{Sg}_{12}$ & $\mathrm{Sg}_{13}$ & tns. \\
\hline$A_{m}$ & & 17.2 & 72.4 & 10.3 & & & & & & & & & & 29 \\
\hline $\mathrm{B}_{\mathrm{m}}$ & 7.7 & 43.6 & 30.8 & 15.4 & & & & & & & & 2.6 & & 39 \\
\hline $\mathrm{C}_{\mathrm{m}}$ & & 24.1 & 58.6 & 13.8 & & & & & & & & 3.4 & & 29 \\
\hline $\mathrm{D}_{\mathrm{m}}$ & 6.5 & 35.5 & 48.4 & 9.7 & & & & & & & & & & 31 \\
\hline $\mathrm{E}_{\mathrm{m}}$ & 2.7 & 35.1 & 54.1 & 5.4 & & & & & & & & 2.7 & & 37 \\
\hline $\mathrm{F}_{\mathrm{m}}$ & & 38.0 & 56.0 & 6.0 & & & & & & & & & & 50 \\
\hline $\mathrm{G}_{\mathrm{m}}$ & 2.2 & 26.1 & 63.0 & 8.7 & & & & & & & & & & 46 \\
\hline $\mathrm{H}_{\mathrm{m}}$ & 4.6 & 26.2 & 50.8 & 7.7 & & 3.1 & & & & 4.6 & & 3.1 & & 65 \\
\hline$I_{m}$ & 2.7 & 34.7 & 38.7 & 10.7 & 2.7 & 2.7 & & & & 2.7 & 1.3 & 4.0 & & 75 \\
\hline $\mathrm{J}_{\mathrm{m}}$ & 2.7 & 36.0 & 40.0 & 6.7 & & 4.0 & & & & 2.7 & & 6.7 & 1.3 & 75 \\
\hline $\mathrm{K}_{\mathrm{m}}$ & 5.5 & 31.5 & 46.6 & 6.8 & 2.7 & 1.4 & & & & 2.7 & & 2.7 & & 73 \\
\hline $\mathrm{L}_{\mathrm{m}}$ & 3.8 & 35.0 & 42.5 & 8.8 & 1.3 & 2.5 & & & & 3.8 & & 2.5 & & 80 \\
\hline $\mathrm{M}_{\mathrm{m}}$ & 1.4 & 28.2 & 53.5 & 7.0 & 1.4 & 4.2 & & & & 2.8 & & 1.4 & & 71 \\
\hline $\mathrm{N}_{\mathrm{m}}$ & 3.8 & 27.4 & 35.8 & 11.3 & 1.9 & 3.8 & & 0.9 & 1.9 & 3.8 & 1.9 & 6.6 & 0.9 & 106 \\
\hline $\mathrm{O}_{\mathrm{m}}$ & 2.2 & 32.6 & 44.6 & 7.6 & 1.1 & 5.4 & & & & 2.2 & & 4.3 & & 92 \\
\hline$P_{m}$ & 6.0 & 31.0 & 42.0 & 8.0 & 2.0 & 5.0 & & & & 2.0 & & 4.0 & & 100 \\
\hline $\mathrm{Q}_{\mathrm{m}}$ & 4.2 & 27.4 & 41.1 & 9.5 & 2.1 & 5.3 & & & & 4.2 & 1.1 & 4.2 & 1.1 & 95 \\
\hline $\mathrm{R}_{\mathrm{m}}$ & 2.9 & 27.2 & 43.7 & 7.8 & 2.9 & 6.8 & & & 1.0 & 1.9 & 1.0 & 4.9 & & 103 \\
\hline$S_{m}$ & 7.4 & 32.0 & 30.3 & 10.7 & 1.6 & 4.9 & & & & 4.1 & 0.8 & 8.2 & & 122 \\
\hline $\mathrm{T}_{\mathrm{m}}$ & 8.6 & 30.3 & 30.3 & 8.6 & 3.9 & 2.6 & 0.7 & & 1.3 & 4.6 & 1.3 & 6.6 & 1.3 & 152 \\
\hline $\mathrm{Sr}_{\mathrm{m}}$ & 9.7 & 10.9 & 9.5 & 2.1 & 1.5 & 3.9 & 11.9 & 5.9 & 6.9 & 14.3 & 7.1 & 14.0 & 2.4 & 750 \\
\hline$A_{a}$ & & 28.3 & 49.1 & & 9.4 & 3.8 & & & & 3.8 & & 5.7 & & 53 \\
\hline $\mathrm{B}_{\mathrm{a}}$ & 1.4 & 37.0 & 47.9 & & 4.1 & & 1.4 & & & 4.1 & & 4.1 & & 73 \\
\hline $\mathrm{C}_{\mathrm{a}}$ & 1.5 & 32.8 & 53.7 & & 3.0 & 1.5 & & & & 3.0 & & 4.5 & & 67 \\
\hline $\mathrm{E}_{\mathrm{a}}$ & & 20.9 & 55.2 & & 10.4 & 3.0 & & & & 4.5 & & 6.0 & & 67 \\
\hline $\mathrm{F}_{\mathrm{a}}$ & & 33.3 & 54.8 & & 4.8 & & & & & 3.6 & & 3.6 & & 84 \\
\hline $\mathrm{G}_{\mathrm{a}}$ & 7.8 & 45.1 & 37.3 & & 2.9 & & & & & 3.9 & & 2.9 & & 102 \\
\hline $\mathrm{H}_{\mathrm{a}}$ & 2.5 & 42.5 & 46.3 & & 2.5 & & & & & 3.8 & 1.3 & 1.3 & & 80 \\
\hline $\mathrm{I}_{\mathrm{a}}$ & & 42.5 & 48.3 & & 3.4 & & & & & 3.4 & & 2.3 & & 87 \\
\hline $\mathrm{Sr}_{\mathrm{a}}$ & 12.0 & 16.5 & 13.4 & & 1.6 & 1.8 & 18.3 & 7.4 & 3.3 & 11.4 & 2.5 & 11.8 & & 552 \\
\hline
\end{tabular}

species such as Aconitum vulparia, Actaea spicata, Aruncus dioicus, Asplenium scolopendrium, Asplenium trichomanes, Cystopteris fragilis, Dryopteris affinis, Lunaria rediviva, Polystichum aculeatum, Polystichum $\times$ bicknelli, and Silene dioica were restricted mainly to mountain "islands" (e.g. doline bottoms and deep valleys) within the "ocean" of oak-hornbeam and beech forests. Only a few of the mountain species (Daphne mezereum, Luzula pilosa, and Stachys alpina $\left.\left(\mathrm{Sg}_{3}\right)\right)$ occurred also in the forests surrounding dolines.

$\mathrm{Sg}_{4}$ and $\mathrm{Sg}_{13}$ species were absent from the flora of the investigated karst surface of the Aggtelek Karst area $\left(5 \mathrm{~km}^{2}\right)$, therefore its 552 vascular plants belonged to 11 species groups (Table 2). Similar to the study region of the Mecsek Mountains, $\mathrm{Sg}_{2}$ and
$\mathrm{Sg}_{3}$ species played an important role in structuring forest communities. $\mathrm{Sg}_{7}, \mathrm{Sg}_{8}, \mathrm{Sg}_{9}, \mathrm{Sg}_{10}$ and $\mathrm{Sg}_{11}$ species occupied similar habitats as in the Mecsek Mountains. $\mathrm{Sg}_{5}$ species (Adoxa moschatellina, Arabis turrita, Asplenium scolopendrium, Asplenium trichomanes, Cystopteris fragilis, Festuca altissima, Lunaria rediviva, Polypodium interjectum, and Ribes alpinum) primarily occurred within the deep and rocky dolines of the karst surface. The number of other mountain species (Carex brevicollis ( $\left(\mathrm{Sg}_{1}\right)$, Actaea spicata, Astrantia major, Daphne mezereum, Dryopteris dilatata, Dryopteris expansa, Polygonatum verticillatum, Prenanthes purpurea, Rosa pendulina, and Senecio ovatus $\left.\left(\mathrm{Sg}_{3}\right)\right)$ occurring also on the plateaus among dolines, was much higher than in the Mecsek Mountains. 
Species composition changed markedly depending on the size of dolines (Table 2). In the small and shallow dolines $\left(A_{m}\right.$ to $\left.G_{m}\right)$, only species belonging to $\mathrm{Sg}_{1}, \mathrm{Sg}_{2}, \mathrm{Sg}_{3}, \mathrm{Sg}_{4}$ and $\mathrm{Sg}_{12}$ were found. In the case of larger and deeper dolines $\left(\mathrm{H}_{\mathrm{m}}\right.$ to $\left.\mathrm{M}_{\mathrm{m}}\right)$, the spectra were wider, and several species of other groups, especially of $\mathrm{Sg}_{5}$ and $\mathrm{Sg}_{6}$, were found (see Fig. 9). The large dolines $\left(\mathrm{N}_{\mathrm{m}}\right.$ to $\left.\mathrm{T}_{\mathrm{m}}\right)$ contained the highest number of species groups with the highest proportions of $\mathrm{Sg}_{5}$, $\mathrm{Sg}_{6}, \mathrm{Sg}_{7}, \mathrm{Sg}_{8}, \mathrm{Sg}_{9}$ and $\mathrm{Sg}_{12}$ species. In contrast, many $\mathrm{Sg}_{5}, \mathrm{Sg}_{10}$ and $\mathrm{Sg}_{12}$ species occurred in the dolines of the Aggtelek Karst area, independently of the doline diameter. Moreover, in most cases, the proportion of $\mathrm{Sg}_{5}$ species was much higher in the Aggtelek Karst area with the maximum of $10.4 \%$ occurring in doline $\mathrm{E}_{\mathrm{a}}$ as compared with that of the Mecsek Mountains, where the maximum (3.9\%) occurred in the largest doline. In all cases, $\mathrm{Sg}_{2}$ and $\mathrm{Sg}_{3}$ species had higher proportions in dolines than in the total flora of the karst surfaces. It is important to note that larger dolines of both regions hold many $\mathrm{Sg}_{5}$ and $\mathrm{Sg}_{6}$ species that are restricted mainly to them.

Results of the MSW analysis indicated the presence of more vegetation units (i.e., No. 1 and No. 2 in the profiles) in dolines $\mathrm{F}_{\mathrm{m}}$ to $\mathrm{T}_{\mathrm{m}}$ and $\mathrm{B}_{\mathrm{a}}, \mathrm{D}_{\mathrm{a}}, \mathrm{E}_{\mathrm{a}}$ and $\mathrm{G}_{\mathrm{a}}$. In contrast, in the case of $A_{m}$ to $E_{m}$ no significant differences were found along the transects. In all but the $\mathrm{F}_{\mathrm{m}}$ doline, $\mathrm{Sg}_{1}, \mathrm{Sg}_{2}$ and $\mathrm{Sg}_{4}$ species (if they occurred in the doline) had a higher proportion in the $2^{\text {nd }}$ unit than in the $1^{\text {st }}$ unit; however, in most cases $\mathrm{Sg}_{3}$ and $\mathrm{Sg}_{12}$ showed the reverse distribution (Fig. 3, 4). From a floristic point of view, the $1^{\text {st }}$ unit showed a marked mountain character due to the occurrence of numerous $\mathrm{Sg}_{5}$ and $\mathrm{Sg}_{6}$ species.

When all vascular plants were taken into consideration, the correlation between species number $\left(\log _{10}\right.$ transformed) and doline area $\left(\log _{10}\right.$ transformed) was positive and significant $(R=0.97, P<0.001$ in the Mecsek Mountains and $R=0.86, P<0.01$ in the Aggtelek Karst area). This relationship was also significant when the oak forest species $(R=0.88, P<0.001)$, beech forest species $(R=0.95, P<0.001)$ and cool-adapted species $(R=0.94, P<0.001)$ of the Mecsek Mountains and the beech forest species $(R=0.87, P<0.005)$ of the Aggtelek Karst area were considered (Fig. 7, 8). However, no such significant correlation was established for cool-adapted species and oak forest species in the Aggtelek Karst area. The slope of the species-area curves ( $z$-values) for all vascular plant species was 0.25 in the Mecsek Mountains and 0.19 in the Aggtelek Karst area, while the slope was higher for oak forest species $(z=0.27)$ and cool-adapted species $(z=0.65)$ in the Mecsek Mountains. The slope was relatively low in the case of beech forest species for both regions $(z=0.18$ in the Mecsek Mountains; $z=0.16$ in the Aggtelek Karst area).

The distribution of plant species in the dolines was significantly nested for both regions: $T=14.08^{\circ}, T_{\text {rand }}=$ $71.38^{\circ}, \mathrm{SD}=1.96^{\circ}, P<0.001$ in the Mecsek Mountains; $T=35.32^{\circ}, T_{\text {rand }}=56.54^{\circ}, \mathrm{SD}=3.11^{\circ}, P<0.001$ in the Aggtelek Karst area. Species that contributed greatest to the matrix disorder include: Fraxinus excelsior, Tilia cordata $\left(\mathrm{Sg}_{2}\right)$, Acer platanoides, Allium ursinum, Arum maculatum, Euphorbia amygdaloides, Galanthus nivalis, Hepatica nobilis, Mercurialis perennis $\left(\mathrm{Sg}_{3}\right)$ and Ruscus hypoglossum $\left(\mathrm{Sg}_{4}\right)$ in the Mecsek Mountains; Melica nutans $\left(\mathrm{Sg}_{2}\right)$, Daphne mezereum, Lathraea squamaria, Ribes uva-crispa, Stachys sylvatica $\left(\mathrm{Sg}_{3}\right)$, Asplenium scolopendrium, Lunaria rediviva $\left(\mathrm{Sg}_{5}\right)$, Circaea lutetiana, Dryopteris carthusiana $\left(\mathrm{Sg}_{6}\right)$, and Sambucus nigra $\left(\mathrm{Sg}_{12}\right)$ in the Aggtelek Karst area.

PCoA showed that the vegetation of smaller dolines of the Mecsek Mountains was very similar to that of upper slopes of larger ones (a representative sample is

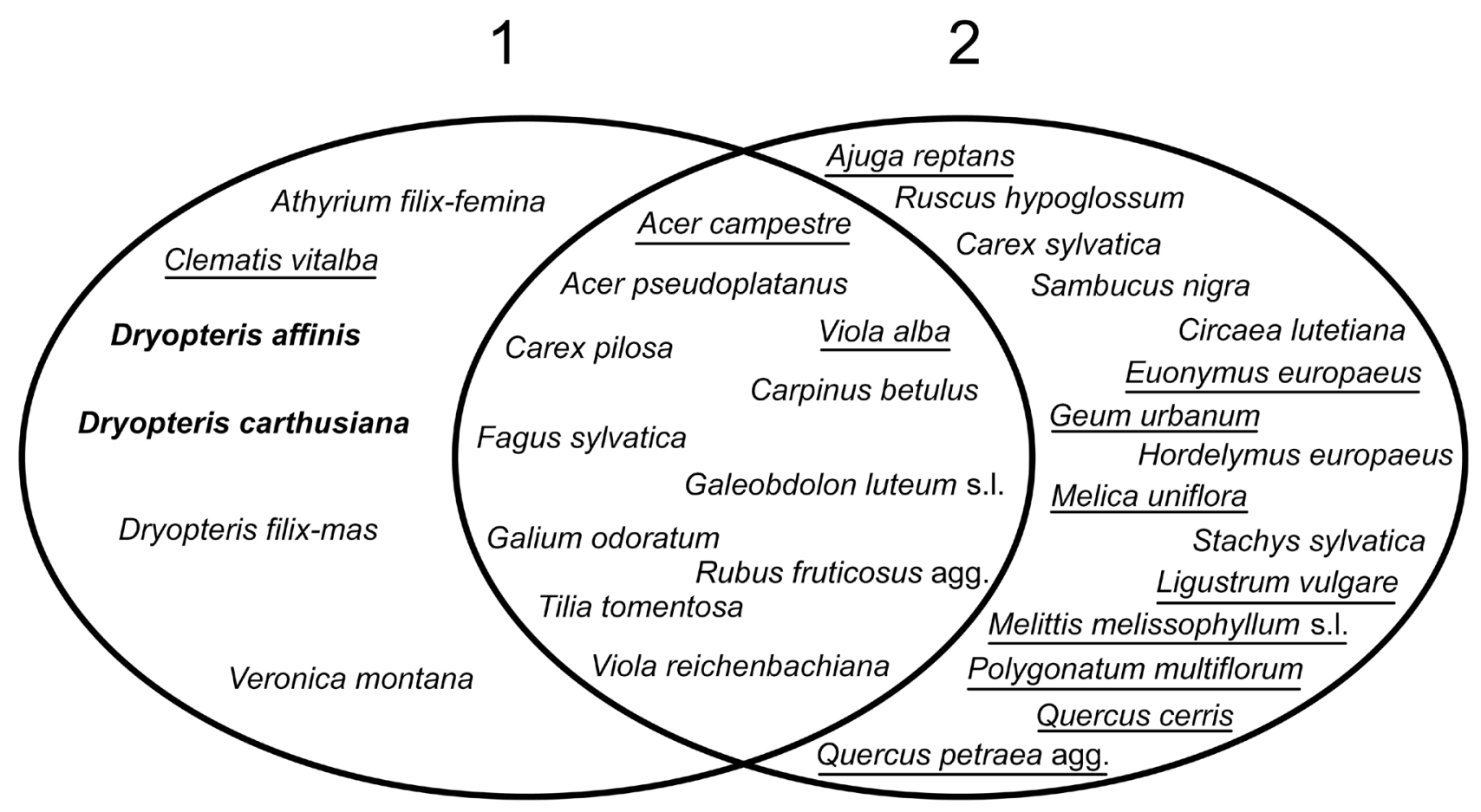

Fig. 9. The species composition of the $\mathrm{I}_{\mathrm{m}}$ doline (a representative sample) along the transect divided into two parts (doline bottom: No. 1, upper slopes and rim: No. 2) by the moving split window (MSW) technique. Species names of deep ravines and gorges $\left(\mathrm{Sg}_{5}\right)$ and wet forests $\left(\mathrm{Sg}_{6}\right)$ are in bold and species names of dry oak forests $\left(\mathrm{Sg}_{1}\right)$ and mesic oak forests $\left(\mathrm{Sg}_{2}\right)$ are underlined. 
shown in Fig. 5). The length of the gradient along the $1^{\text {st }}$ axis was the longest in the largest doline and the slopes were covered by different types of forests. Plots of the ravine forests were on the left side of the scatter in the given sample. However, the plots of beech forests and oak-hornbeam forests were not separated from each other. Despite the relatively high depth/ diameter ratios of some smaller dolines (e.g. $\mathrm{B}_{\mathrm{m}}$ : 0.25; $\left.\mathrm{E}_{\mathrm{m}}: 0.23\right)$, they did not contain vegetation types that were not present in larger dolines. In contrast, as the representative sample shows (Fig. 6), ordination of the plots of the Aggtelek Karst area indicated a different pattern. Plots of $\mathrm{E}_{\mathrm{a}}$ at one end of the gradient showed a relatively distinct vegetation type that was absent from larger dolines and was identified as ravine forest in the field. However, scree forest was absent from this doline. Similarly to the Mecsek Mountains, the length of the gradient along the $1^{\text {st }}$ axis was the longest in the largest doline.

\section{DISCUSSION}

Humanity is rapidly destroying habitats that are natural, species-rich and are an important source of knowledge about life-history evolution (Pimm \& Raven, 2000). In addition, another adverse factor is the effect of climate change caused by global warming, which has caused distributional shifts towards the poles or higher altitudes accompanied by various behavioural changes in the case of several species (Walther et al., 2002; Erschbamer et al., 2011). However, many species choose other possible migration routes restricting their distribution to sheltered sites such as dolines, fens, ponds, valleys and other cold and humid places (Schindler et al., 1996; Kochjarová et al., 1997; Bátori et al., 2012).

Our study yielded three main results. First, the investigated dolines can be recognized as refugia for many vascular plant species. Second, doline geometry significantly influences the distribution of plant species. Third, species preservation in the dolines is not influenced by the type of regional climate.

The role of dolines in preserving different kinds of species is well-known (Horvat, 1953; Özkan et al., 2010; Bátori et al., 2011), although species preservation is significantly influenced by many factors (Geiger, 1950; Lehmann, 1970; Favretto \& Poldini, 1985; Whiteman et al., 2004). Our study revealed that dolines of both investigated regions provide good habitat for many species adapted to different temperature and moisture regimes. According to the results of the MSW analysis, vegetation of smaller dolines of the Mecsek Mountains does not change substantially along the transects, however, the slopes of larger dolines of both regions contain more vegetation units with their own species. When all plant species of the dolines are considered, the $z$-values $(z=0.25$ and $z=0.19$, respectively) are in good agreement with those obtained previously for oceanic and habitat islands (Begon et al., 2006). Our results suggest that the larger dolines of the Mecsek Mountains have much greater impact on the distribution of oak forest species than the smaller ones. Larger dolines have larger south-facing slopes, which allow increased insolation during daytime. The species-area curve for oak forest species $(z=0.27)$ is much steeper than that for beech forest species $(z=0.18$ in the Mecsek Mountains; $z=0.16$ in the Aggtelek Karst area). This means that, for beech forest species, dolines serve as island-like habitats to a lesser degree than for oak forest species (cf. Rockwood, 2006). We did not find linear correlation between the number of oak forest species and doline area in the Aggtelek Karst area. This is due to the fact that some dolines of this region have vertical rocky walls, which modify the effects of solar insolation on species preservation of the south-facing slopes. In our former study (Bátori et al., 2012), we reported that larger dolines of the Mecsek Mountains act as refugia for many cool-adapted plants of the summer flora. If considering the steepness of the species-area curve of cool-adapted species in the Mecsek Mountains $(z=0.65)$, we can conclude that larger dolines play an essential role in preserving many plant species that are particularly vulnerable to climatic change. This is due to the linear relation between doline diameter and depth, which results in lower temperatures in larger dolines. As the multivariate analyses (MSW, PCoA) and field observations revealed, larger dolines of this region always contain the vegetation types of the smaller dolines. However, cool-adapted species and vegetation types of the Aggtelek Karst area show a very different pattern. Although vascular plant assemblages are significantly nested in both regions, we should always take into consideration those species that appeared in unexpected places (Atmar \& Patterson, 1993; Heino et al., 2009). For example, many idiosyncratic species of the Aggtelek Karst area belong to the groups of $\mathrm{Sg}_{5}$ and $\mathrm{Sg}_{6}$, highlighting the role of some smaller dolines as refugia. The smallest doline of this region $\left(A_{a}\right)$ contains much more cool-adapted species than some larger ones (e.g. $G_{a}$ and $H_{a}$ ). This can be explained by the geometry, because this doline is deep relative to its width (depth/diameter ratio is 0.38 ) and, in addition, has rocky walls. The steep slopes of some smaller dolines are covered by ravine forests, which vegetation type is absent from many large dolines of this region.

Both investigated regions are rich in habitats and plant species. Oak-hornbeam and beech forest communities dominate most of the plateaus and hill slopes (Jakucs \& Jurko, 1967; Kevey \& Borhidi, 1998), ecologically connecting the numerous dolines scattered in these forests. However, the proportion of different types of species differs markedly between the karst surfaces and individual dolines. The different regional climates of the two regions studied resulted in different species pools from which local communities are drawn (cf. Pärtel et al., 1996). This is in good agreement with the results of former studies, which revealed that many plant species have a high degree of range equilibrium with actual climate (Webb, 1986; Prentice et al., 1991). Considering our study regions, $\mathrm{Sg}_{4}$ species play an important role in structuring plant communities of the Mecsek Mountains, but they are absent from the study region of the Aggtelek Karst area, although some Illyrian species do occur in other 
parts of the Aggtelek Karst area. Obviously, these differences are somewhat understandable if we try to identify and clarify the late glacial and post-glacial evolution of the Carpathian Basin. Investigation of loess profiles, lake sediments and archaeological sites in different parts of the Carpathian Basin revealed that between ca. 32000 and 16000 years $\mathrm{BP}$ recurring boreal forest-steppe characterised the area (Willis et al., 1998; Rudner \& Sümegi, 2001). After the Younger Dryas (III) (ca. 11000 BP), warming with increasing summer insolation allowed species to expand northward, mainly from the Balkan Peninsula. In the Boreal and Atlantic phases of the Holocene, the limestone flora of Hungary became more diverse with many vascular plant species migrating from the south. After the Holocene climate optimum (ca. $5000 \mathrm{BP}$ ), when the climate became cooler, many warm-adapted plants of northern Hungary have been forced into refugia (e.g. south-facing rocky outcrops), but the Mecsek Mountains and its surroundings preserved its sub-Mediterranean character (Borhidi, 2006). Under the present-day climate regime of the Aggtelek Karst area, mountain elements could occupy the karst surface at two levels. First, many mountain species (e.g. Daphne mezereum, Polygonatum verticillatum) occur in all favourable habitats, both on plateaus among dolines and in dolines; second, other mountain plants (e.g. Lunaria rediviva, Ribes alpinum) are restricted mainly to rocky dolines (see Fig. 4.). In contrast, due to the warmer climate, mountain species of the Mecsek Mountains occur mainly in dolines (see Fig. 3.) and in deep valleys (cf. Kevey, 1997). However, dolines of both regions play the same role in the preservation of vascular plant species. Since larger dolines of both regions were formed in the Pleistocene (Hoyk, 1999; Telbisz \& Ádám, 2011), they might play an important role as refugia for many vascular plants in different periods of geologic time, highlighting the dolines as target objects for vegetation history studies. For example, Stachys alpina, a cold-stage relict of the Mecsek Mountains (Simon, 2000), might have survived in the bottom of larger dolines during periods of unfavourable conditions (e.g. in the Atlantic phase of Holocene).

Our results suggest that the effects of doline geometry on temperature inversion strength, latitude, rockiness, vegetation cover and vegetation history exert a major impact on plant growth and survival in dolines. We can conclude that karst dolines of Hungary can be considered as potential refugia for many vascular plant species under future global warming, therefore they are particularly important from a conservation point of view. Due to the recent increases in the degradation of doline vegetation (e.g. deforestation, overgrazing) in some areas of Hungary (Bárány-Kevei, 2011), there is a pressing need to focus conservation efforts on the preservation of the valuable flora of dolines. The classification of species presented in this paper will be used to prioritize species groups on which to focus management and to identify those environmental factors which require further studies.

\section{ACKNOWLEDGEMENT}

We thank Kornél Baráth, Krisztián Kóczián and Nóra Tóth for assistance with field work.

\section{REFERENCES}

Arrhenius O., 1921 - Species and area. Journal of Ecology, 9: 95-99. http://dx.doi.org/10.2307/2255763

Atmar W. \& Patterson B.D., 1993 - The measure of order and disorder in the distribution of species in fragmented habitat. Oecologia, 96: 373-382. http://dx.doi.org/10.1007/BF00317508

Atmar W. \& Patterson B.D., 1995 - The nestedness temperature calculator: a Visual Basic program, including 294 presence-absence matrices. AICS Research Inc., University Park, NM, USA and The Field Museum, Chicago, IL, USA.

Ádám L., Marosi S. \& Szilárd J., (Eds.) 1981 - A Dunántúlidombság (Dél-Dunántúl). Magyarország tájföldrajza 4. Akadémiai Kiadó, Budapest, 704 p.

Barnard P., Brown C.J., Jarvis A.M., Robertson A. \& van Rooyen L., 1998 - Extending the Namibian protected area network to safeguard hotspots of endemism and diversity. Biodiversity and Conservation, 7: 531-547. http://dx.doi.org/10.1023/A:1008831829574

Bárány-Kevei I., 2011 - Changes in the vegetation of dolines in Aggtelek and Bükk Mountains. Acta Climatologica et Chorologica, 44-45: 25-30.

Bartha A., 1933 - Szakosztály ügyek - Dracocephalum ruyschiana a Bükk hegységben. Botanikai Közlemények, 30: 114 .

Bátori Z., Baráth K. \& Csiky J., 2006 - A Dryopteris affinis (Löwe) Fras.-Jenk. elöfordulása a Mecsekben. Flora Pannonica, 4: 3-8.

Bátori Z., Csiky J., Erdős L., Morschhauser T., Török P. \& Körmöczi L., 2009 - Vegetation of the dolines in Mecsek Mountains (South Hungary) in relation to the local plant communities. Acta Carsologica, 38: 237-252.

Bátori Z., Gallé R., Erdős L. \& Körmöczi L., 2011 Ecological conditions, flora and vegetation of a large doline in the Mecsek Mountains (South Hungary). Acta Botanica Croatica, 70: 147-155.

http://dx.doi.org/10.2478/v10184-010-0018-1

Bátori Z., Körmöczi L., Erdős L., Zalatnai M. \& Csiky J., 2012 - Importance of karst sinkholes in preserving relict, mountain and wet woodland plant species under sub-Mediterranean climate: a case study from southern Hungary. Journal of Cave and Karst Studies, 74: 127-144.

http://dx.doi.org/10.4311/2011LSC0216

Beck v. Mannagetta G., 1906 - Die Umkehrung der Pflanzenregionen in den Dolinen des Karstes. Sitzungsberichte der Kaiserliche Akademie der Wissenschaften in Wien, 65: 3-4.

Begon M., Townsend C.R. \& Harper J.L., 2006 - Ecology: From Individuals to Ecosystems. Blackwell, Oxford, 738 p.

Borhidi A., 2006 - Magyarország növényföldrajza új megvilágitásban. In: Vizi E.Sz. (Ed.). Székfoglalók a Magyar Tudományos Akadémián. Budapest: Magyar Tudományos Akadémia: 299-325.

Breg M., 2007 - Degradation of dolines on Logaško Polje (Slovenia). Acta Carsologica, 36: 223-231.

Cardoso P., 2012 - Diversity and community assembly patterns of epigean vs. troglobiont spiders in the Iberian Peninsula. International Journal of Speleology, 41: 8394. http://dx.doi.org/10.5038/1827-806X.41.1.9

Culver D.C., Holsinger J.R. \& Baroody R., 1973 - Toward a predictive cave biogeography: the Greenbrier valley as a case study. Evolution, 27: 689-695. http:/ / dx.doi.org/10.2307/2407201 
Culver D.C. \& Sket B., 2000 - Hotspots of subterranean biodiversity in caves and wells. Journal of Cave and Karst Studies, 62: 11-17.

Dakskobler I., Sinjur I., Veber I. \& Zupan B., 2008 Localities and sites of Pulsatilla vernalis in the Julian Alps. Hacquetia, 7: 47-69. http://dx.doi.org/10.2478/v10028-008-0004-5

Dixon J.V., 2011 - The role of small caves as bathibernacula in Iowa. Journal of Cave and Karst Studies, 73: 21-27. http://dx.doi.org/10.4311/jcks20101sc0145

Egli B.R., 1991 - The special flora, ecological and edaphic conditions of dolines in the mountains of Crete. Botanica Chronica, 10: 325-335.

Egli B.R., 1993 - Ökologie der Dolinen im Gebirge Kretas (Griechenland). Inaugural-Dissertation zur Erlangung der philosophischen Doktorwürde vorgelegt der Philosophischen Fakultät II der Universität Zürich, Zürich, 275 p.

Egli B., Gerstberger P., Greuter W. \& Risse H., 1990 Horstrissea dolinicola, a new genus and species of umbels (Umbelliferae, Apiaceae) from Kriti (Greece). Willdenowia, 19: 389-399.

Erschbamer B., Unterluggauer P., Winkler E. \& Mallaun M., 2011 - Changes in plant species diversity revealed by long-term monitoring on mountain summits in the Dolomites (northern Italy). Preslia, 83: 387-401.

Favretto D. \& Poldini L., 1985 - The vegetation in the dolinas of the karst region near Trieste. Studia Geobotanica, 5: 5-18.

Gargano D., Vecchio G. \& Bernardo L., 2010 - Plant-soil relationships in fragments of Mediterranean snow-beds: ecological and conservation implications. Plant Ecology, 207: 175-189.

http:/ /dx.doi.org/10.1007/s11258-009-9663-7

Geiger R., 1950 - Das Klima der bodennahen Luftschicht: Ein Lehrbuch der Mikroklimatologie, 4. Auflage. Friedr. Vieweg \& Sohn, Braunschweig, 460 p.

Heino J., Mykrä H. \& Muotka T., 2009 - Temporal variability of nestedness and idiosyncratic species in stream assemblages. Diversity and Distributions, 15: 198-206. http://dx.doi.org/10.1111/j.1472-4642.2008.00513.x

Horvat I., 1953 - Vegetacija ponikava. Geografski Glasnik, 14/15: 1-25.

Hoyk E., 1999 - Investigation of the vegetation and soil in the dolinas of Western Mecsek Mountains, South Hungary. Acta Carsologica, 28: 105-114.

Jakucs P. \& Jurko A., 1967 - Querco petraeae-Carpinetum waldsteinietosum, eine neue Subassoziation aus dem slowakischen und ungarischen Karstgebiet. Biologia, 22: 321-335.

Kevey B., 1997 - A Nyugati-Mecsek szurdokerdei [Scutellario altissimae-Aceretum (Horvát A. O. 1958) Soó et Borhidi in Soó 1962]. - In: Borhidi A. \& Szabó L.Gy. (Eds.) Studia Phytologica Jubilaria. Dissertationes in honorem jubilantis Adolf Olivér Horvát Doctor Academiae in annoversario nonagesimo nativitatis 1907-1997. Pécs: 75-99.

Kevey B. \& Borhidi A. 1998 - Top-forest (Aconito anthoraeFraxinetum orni). A special ecotonal case in the phytosociological system (Mecsek Mts., South Hungary). Acta Botanica Hungarica, 41: 27-121.

Király G., (Ed.) 2009 - Új magyar füvészkönyv. Aggteleki Nemzeti Park Igazgatóság, Jósvafő, 616 p.

Kochjarova J., Marhold K. \& Hrouda L., 1997 Contribution towards the knowledge of the flora and vegetation of the Jánska dolina Valley and Mt. Ohnište in the Nizke Tatry Mts. (Slovakia). Preslia, 69: 333-358.

Körmöczi L., 2005 - On the sensitivity and significance test of vegetation boundary detection. Community Ecology, 6: 75-81.

http://dx.doi.org/10.1556/ComEc.6.2005.1.8
Körmöczi L., 2011 - Vegetációmintázatok és élöhelyi mintázatok tér-idő kapcsolatai. Habilitation theses, University of Szeged, Szeged, 30 p.

Lausi D., 1964: Vorläufiger Überblick über die Vegetation der Triester Karstdolinen. Acta Botanica Croatica, 4: 65-71.

Lazarević P., Lazarević M., Krivošej Z. \& Stevanović V., 2009 - On the distribution of Dracocephalum ruyschiana (Lamiaceae) in the Balkan Peninsula. Phytologia Balcanica, 15: 175-179.

Lehmann A., 1970 - Tarvágás által okozott ökológiai változások az abaligeti karszton. Pécsi Műszaki Szemle, 25: 15-21.

Lovász Gy., 1971 - Adatok az Abaligeti-karszt geomorfológiai és hidrológiai jellemzéséhez. Földrajzi Értesítő, 20: 283-296.

Marosi S. \& Somogyi S., (Eds.) 1990 - Magyarország kistájainak katasztere I-II. MTA Földrajztudományi Kutató Intézet, Budapest, 479 p.

Novak T., Perc M., Lipovšek S. \& Janžekovič F., (2012) Duality of terrestrial subterranean fauna. International Journal of Speleology, 41: 181-188.

http://dx.doi.org/10.5038/1827-806X.41.2.5

Özkan K., Gulsoy S., Mert A., Ozturk M. \& Muys B., 2010 - Plant distribution-altitude and landform relationships in karstic sinkholes of Mediterranean region of Turkey. Journal of Environmental Biology, 31: 51-61.

Pärtel M., Zobel M., Zobel K. \& van der Maarel E., 1996 - The species pool and its relation to species richness: evidence from Estonian plant communities. Oikos 75: 111-117. http://dx.doi.org/10.2307/3546327

Pimm S.L. \& Raven P., 2000 - Biodiversity: extinction by numbers. Nature, 403: 843-845.

http://dx.doi.org/10.1038/35002708

Prentice I.C, Bartlein P.J. \& Webb T. III., 1991 - Vegetation and climate change in Eastern North America since the last glacial maximum. Ecology, 72: 2038-2056. http://dx.doi.org/10.2307/1941558

$\mathrm{R}$ Development Core Team, $2009-R$ : A language and environment for statistical computing. $\mathrm{R}$ Foundation for Statistical Computing, Vienna.

Redžić S., Barudanović S., Trakić S. \& Kulijer D., 2011 - Vascular plant biodiversity richness and endemorelictness of the karst mountains Prenj, Cursniva and Cabulja in Bosnia and Herzegovina (W. Balkan). Acta Carsologica, 40: 527-555.

Rockwood L.L., 2006 - Introduction to population ecology. Blackwell Scientific Publications, Oxford, 339 p.

Rudner E.Z. \& Sümegi P., 2001 - Recurring Taiga foreststeppe habitats in the Carphatian Basin in the Upper Weichselian. Quaternary International, 76/77: 177-189. http://dx.doi.org/10.1016/S1040-6182(00)00101-4

Schilthuizen M., Liew T.S., Elahan B.B. \& Lackman-Ancrenaz I., 2005 - Effects of karst forest degradation on pulmonate and prosobranch land snail communities in Sabah, Malaysian Borneo. Conservation Biology, 19: 949-954.

Schindler D.W., Bayley S.E., Parker B.R., Beaty K.G., Cruikshank D.R., Fee E.J., Schindler E.U. \& Stainton M.P., 1996 - The effects of climatic warming on the properties of boreal lakes and streams at the Experimental Lakes Area, northwestern Ontario. Limnology and Oceanography, 41: 1004-1017. http://dx.doi.org/10.4319/lo.1996.41.5.1004

Simon T., 2000 - A magyarországi edényes flóra határozója. Nemzeti Tankönyvkiadó, Budapest, 976 p.

Soó R., 1980 - A magyar flóra és vegetáció rendszertaninövényföldrajzi kézikönyve VI. Akadémiai Kiadó, Budapest, $556 \mathrm{p}$.

Stuckey R.L., 1983 - Absence of certain aquatic vascular plants from the prairie peninsula. In: Brewer R. (Ed.). Proceedings of the eighth North American Prairie Conference. Kalamazoo: Western Michigan Univ.: 97-104. 
Telbisz T. \& Ádám E., 2011 - A Felsö-hegy, a Mészkö-tető, a Barkai- és a Szádelöi-fennsík domborzati és töbörmorfometriai elemzése térinformatikai eszközökkel. Karsztfejlődés, 16: 87-102.

Ujvárosy A., 1998 - Földrajzi helyzet, éghajlati viszonyok. In: Baross G. (Ed.). Az Aggteleki Nemzeti Park. Budapest: Mezőgazda Kiadó: 22-26.

Vojtkó A., 1997 - Új adatok a Tornai-karszt flórájához és vegetációjához. Kitaibelia, 2: 248-249.

Vojtkó A., 2003 - A Tornai-karszt töbreinek cönológiai jellegzetességei. Botanikai Közlemények, 90: 167-168.

Vojtkó A., 2004 - Az Aggteleki-karszt növényföldrajzi jellegzetességei. Acta Academiae Paedagogicae Agriensis, 25: 73-99.

Walther G., Post E., Convey P., Menzel A., Parmesan C., Beebee T.J.C., Fromentin J.M., Hoegh-Guldberg O. \& Bairlein F., 2002 - Ecological responses to recent climate change. Nature, 416: 389-437. http://dx.doi.org/10.1038/416389a

Webb T. III., 1986 - Is vegetation in equilibrium with climate? How to interpret late-Quaternary pollen data. Vegetatio, 67: 75-91.

http://dx.doi.org/10.1007/BF00037359
Webster R., 1978 - Optimally partitioning soil transects. Journal of Soil Science, 29: 388-402.

http://dx.doi.org/10.1111/j.1365-2389.1978.tb00789.x

Whiteman C.D., Haiden T., Pospichal B., Eisenbach S. \& Steinacker R., 2004 - Minimum temperatures, diurnal temperature ranges, and temperature inversion in limestone sinkholes of different sizes and shapes. Journal of Applied Meteorology, 43: 1224-1236.

http://dx.doi.org/10.1175/15200450(2004)043<1224:MTDTRA >2.0.CO;2

Willis K.J., Rudner E. \& Sümegi P., 1998 - The full-glacial forests of central and southeastern Europe. Quaternary Research, 53: 203-213.

http://dx.doi.org/10.1006/qres.1999.2119

Wraber T., 1995 - Cerastium dinaricum G. Beck \& Szysz. - a new species in the flora of Slovenia. Hladnikia, 4: 11-18.

Yannitsaros A.G., Constantinidis T.A. \& Vassiliades D.D., 1996 - The rediscovery of Biebersteinia orphanidis Boiss. (Geraniaceae) in Greece. Botanical Journal of the Linnean Society, 120: 239-242.

http://dx.doi.org/10.1111/j.1095-8339.1996.tb00773.x

Zalatnai M. \& Körmöczi L., 2004 - Fine scale pattern of the boundary zones in alkaline grasslands communities. Community Ecology, 5: 235-246.

http://dx.doi.org/10.1556/ComEc.5.2004.2.11 